\title{
MINANGKABAU AESTHETICS IN INDONESIAN CINEMA
}

\author{
Herry Nur Hidayat ${ }^{1}$, Bani Sudardi ${ }^{2}$, Sahid Teguh Widodo ${ }^{3}$, Sri K Habsari ${ }^{4}$ \\ ${ }^{1}$ Universitas Sebelas Maret and Universitas Andalas, Padang, Indonesia; \\ ${ }^{2,3,4}$ Universitas Sebelas Maret, Surakarta, Indonesia,Email: herrynh@hum.unand.ac.id
}

\section{ABSTRACT:}

This article attempts to construct the Minangkabau aesthetic in Indonesian cinema. The emergence of conflict based on Minangkabau ethnicity in a movie is why the Minangkabau aesthetic construction is built. From the perspective of identity theory, the film is seen as a social process, including ethnic content. Considering Indonesia's diversity, this Minangkabau aesthetic construction cannot leave the Nusantara's aesthetic concept. Mise en scene analysis is the first step to determine the Minangkabau element. The categorization of landscapes and traditions associated with Minangkabau in films conclusively becomes the Minangkabau aesthetic construction found in Indonesian cinema. This construction is expected to consider Minangkabau ethnicity or fictional content in art, especially movies.

Article Received: 18 October 2020, Revised: 3 November 2020, Accepted: 24 December 2020

\section{Introduction}

In its history, the Minangkabau-contented in Indonesian cinema seemed to be dominated by the adaptation of literary works from the Balai Pustaka and Pujangga Baru era. Sitti Noerbaja (1941) is based on the romance Marah Rusli. Salah Asuhan by Abdul Muis was appointed to the big screen by Asrul Sani with the same title in 1972. Di Bawah Lindungan Ka'bah, Hamka's work was brought to the big screen twice in 1977 and 2011. Tenggelamnya Kapal van Der Wijck (2013) was also appointed from Hamka's romance. Besides, there are three film raise Minangkabau folklore, namely Malin Kundang Anak Durhaka (1971), 7 Manusia Harimau (1986), and Palasik (2015). Then, Tabula Rasa's (2014) release seems to give a new color to Indonesian films, especially those with Minangkabau locality. Presenting the life of the Minangkabau diaspora in overseas lands, this film also presents traditional Minangkabau culinary content.

Films containing Minangkabau locality also did not escape discussions and polemics. Cinta Tapi Beda, by Hanung Bramantyo, became the topic of conversation because it was considered to have insulted Minangkabau, Java, and even Islam. This film tells Diana's story, from Padang and is a Catholic, with Cahyo, from Yogyakarta, a
Moslem. It intricacies of their relationship with different beliefs. However, as if knowing the author's intent and purpose, the audience tends not to accept the film's story's contents. The audience accused this film of discrediting Minangkabau with the statement, Minangkabau is Islam. Hanung, as the director, finally decided to stop the screening of the film (Noviandi, 2013). In fact, in 2018, this film was sued in the realm of law (Priyambodo, 2018). The release of Merantau (2009) is considered a milestone in the revival of local content (Minangkabau) in Indonesian cinema. More related to film titles and action featuring silek (silat), Merantau raises a fairly thick element of Minangkabau (ica, 2009). On the other hand, the Governor of West Sumatra, Irwan Prayitno, said that the film Merantau lacked the philosophy of silat and the tradition of migrating for the Minangkabau people (Indah, 2009).

It seems the audience's sensitivity towards film content is still a challenge in the Indonesian cinema development. Besides dealing with Lembaga Sensor Film (Film Censorship Institutions), film creators in Indonesia still have to deal with audience censorship. The film audience (and other arts) in Indonesia have not been able to sort out the realities in the works from the real facts. The audience's closeness to the 
film's content could be one of the possibilities that cause this behavior. Thorough knowledge of something can be the beginning of rejection because it does not match expectations.

It can be said that film audiences in Indonesia still tend to accept the repetition pattern, which is a common assumption for certain ethnic people (stereotypes). When compared, the public is more accepting of the Minangkabau's image being stingy, the Javanese who succumbs, the stubborn Batak people as depicted in one of the soap operas, Suami-Suami Takut Istri. Indonesian audiences are more receptive to the film by Djajakusuma Malin Kundang Anak Durhaka (1971) than the short story of Malin Kundang Ibunya Durhaka by A.A. Navis. The audience tends to accept the use of the Minangkabau language in dialogue, the appearance of gonjong roofs, or even merely selecting a setting in the West Sumatra region as Minangkabau content. The display's inconsistency with the audience's knowledge, in the end, has great potential to give rise to massive rejection. The knowledge that is commonly known and accepted by the public can build sentiments that tend to be chauvinist. That is in line with the statement of Aumont et al. (1992) that cinema provokes an increase in chauvinism through its contents.

Apart from the assumption as an exploitation, the content of Minangkabau locality in films is widely considered to help develop knowledge and understanding of sustainability and preserve traditional Minangkabau culture and tradition. The strength of the matrilineal system in the matchmaking and marriage process shown in Tenggelamnya Kapal van Der Wijck is seen as a representation of the Minangkabau's rigidity matrilineal culture (Trisnawati \& Yesicha, 2018). Besides, this film shows primordial ties and ethnocentrism, which are an obstacle to multiculturalism in the Indonesian context (Thalib, 2017). Meanwhile, surau as a traditional Minangkabau education system (Azra, 2003), which appears in the film Surau dan Silek, actually presents the reality of different views of the surau and silek of the two Minangkabau generations (Arief, 2018). The traditional values and folklore in Harimau Tjampa are considered similar to the romanticism in the style of films during the colonial period (Anggraini, 2016). Harimau Tjampa is one of the movies at the beginning of the development of Indonesian films that raised nationalism while still carrying traditional values (Minangkabau).

Several responses to films containing Minangkabau indicate the process of acceptance of this form of artistic expression. Regardless of positive or negative, audience responses are a form of the same background knowledge about Minangkabau. Minangkabau is one of the ethnic groups in Indonesia, which has a dynamic culture. Minangkabau people are known to adapt to new environments when they migrate quickly. Their hometown tradition brought overseas as a form of identity besides a condition of longing for their ancestral land. It can be said that talking about Indonesian cinema's history cannot be separated from the Minangkabau. In a sense, the Minangkabau traditional culture has influenced film development as an industry in Indonesia. The emergence of the Minangkabau element in the film as a representation of ethnic identity requires an adequate understanding of the Minangkabau aspects. How can an element of locality be called a part of Minangkabau? Is philosophy, tradition, art, landscape, and language sufficient to measure the Minangkabau aspects in a film? This article attempts to present search results and efforts to compile Minangkabau's aesthetics concept and construction in cinema. Of course, the discussion does not break away from the film's context as an industrial product.

\section{Film and Identity}

Film is often said to be a form of representation and even a reflection of life. Viewers often feel that they have experienced the same events as those shown in the film (Kurniasih, 2019). This assumption is acceptable because, in fact, films "present" reality. Through 
audio-visual imagery and technology, films present the impression of reality and build that impression into reality. Because of its convincing nature, Metz (1991) said that films could "move" audiences, has the power to draw crowds.

Visual imagery is the most prominent element in building this impression. Through this visual image, the audience "blends" with the film. Montage in the film is an advantage over photography. If photography presents a visual image of the past, a film with montage techniques brings events as their present form. The past in film is a narrative building through flashbacks. That is where the power of film narrative builds instantaneous visual images (Metz, 1991).

On the other hand, Buckland (2000) offers a different perspective on reaching film meaning. The impression of unity and continuity experienced by every viewer in the cinema is based on standard codes that unconsciously form a specific, structured, and sometimes provide the same understanding. This hierarchical arrangement - between the unconscious and the coding system behind it - shows that film continuity is a surface illusion and so-called 'impression of reality.' Film semiotics encourage intersections between films and their references, break relationships that are thought to be essential, and show that filmic meaning results from a coded system, not just a relationship between an image and its reference (referent).

However, we cannot deny that one aspect of the semiotic meaning of a work (film) comes from the concept of audience acceptance. Ehrat (2005) states that understanding a film will involve the audience's knowledge as part of the meaning process. However, he added that if the film is perceived generally as a real-world object, like a picture in a particular time, or a similar pattern, its vision has failed.

Like literature, the film is a means of communication in the form of symbols. Symbols are conveyed elaborately through sound and visual dimensions. Like paintings and photographs, the film presents light and shadow.
Like a sculpture, a film offers three-dimensional spaces. Like a pantomime, films show moving images. Like dance, films have complex rhythms involving music and poetry. Films communicate through images, metaphors, and symbols. Like dramas, films present visual and verbal communication, visuals through actions and gestures, and verbally through dialogue. Like a novel, a film stretches or compresses space and time to move as you like as a form of story dynamics (Boggs \& Petrie, 2008).

As a symbol and means of communication, the film is a project that is not without problems. Films are natural reflections that cannot escape their consequences on culture and audiences (Buckland, 2000). Films with ethnic or social identity content still risk getting an unexpected response from the ethnic or social group. This condition is due to the nature of social identity associated with many people (person). Ashforth \& Mael (1989) stated that social identity is a perception of group unity, arising from individual categorization related to group differentiation and pride, the importance of groups, perceptions of group stereotypes, and group origins. That is what ultimately leads to aspects of socialization, role conflict, and inter-group relationships. Therefore, it is not surprising that various reactions to a work of art (film) elevate a social group's identity but do not conform to the group's perception.

However, regardless of how to treat films as the subject of a study, films are a social practice. One aspect that must be taken into account is the film's aspect as a work of art. Creativity and technology continue to encourage the development of films to become more "better" aesthetically. The content in the film has also become more diverse as the genre develops. Art cinema, teen movies, thrillers, martial art, and horror are among the rich content of film themes. Art ideology has become the spearhead of film artists who form the basis of film festivals. However, the growth and development of the art aspect in a film must ultimately be subject to the second aspect, namely the industry. The pressure 
of commercial ideology, in the end, overcame artistic idealism. The high cost of the filmmaking process eventually made film artists become mere film workers. Production profit becomes the first consideration for film production. Film advertising has also transformed to follow in the footsteps of corporate growth by manipulating festivals, criticism, and even the film genre. The emergence of independent films as a form of resistance was defeated by large corporate capital. This description is in line with Turner's (2003) statement that the film contains something big as a social representation. In the end, it is not enough to study films only through narrative elements. The relationship between image, audience, narrative, ideology, industry, and culture should also get attention.

In the assumption that locality and ethnicity are a form of regional cultural preservation, their appearance in films can be seen as a form of industrial exploitation. There is a difference between content and material. The content suggests the motive, theme, and story development. Material is "everything that is controlled and manipulated" by the artist (T. W. Adorno, 1997). If tradition and culture are seen as elements that can change social life, someone can manipulate them for specific interests. This is the main objective of the culture industry. Culture is no longer a natural phenomenon but an artificial phenomenon as a product and commodity for consumption (Khandizaji, 2017). The relationship between place (in this case, ethnicity) and products in the cultural industry is often so strong that it becomes an essential element of a company's success in the broader market. Markers related to place can be a selling power that a company can use to increase its competitive position (Power \& Scott, 2004). These statements imply that Minangkabau's content in films is material for creators in the context of the culture industry. Art, tradition, culture, and other elements of Minangkabau are merely commodities that are processed in such a way to make a profit. Concerning socio-cultural practices and the impression of reality, the film results from a deliberately conditioned narrative process. There are specific formulas that involve many individuals in making films. The story idea and its concretize are a narrative perception of reality, which is then compiled into an imaginary reality. Metz (1991) called it the power of unreality. The pictures, sounds, dialogues, and even music in the film is a story that "says something," which is deliberately produced.

Ethnicity in a film cannot only be viewed as a representation of a particular ethnicity. As part of the social process, ethnicity is also an ideological discourse that is continuously changing and developing. The tension between tradition and technology in forming ethnicity also influences and contributes to building social structures through symbols that appear in films. Besides, Indonesia's ethnic diversity and mobility are also essential factors in changing ethnic identities. The contact with other ethnic and the stereotypes that develop in society can be a possible cause of the continuing change and development of ethnicity in Indonesia, especially Minangkabau.

\section{Minangkabau Aesthetics}

Talking about Minangkabau is not just talking about West Sumatra. Minangkabau is better known as a form of culture than as a form of state or kingdom in history (Navis, 1984). It can be concluded that Minangkabau contains the notion of geographical, economic, political, and cultural unity. In this sense, the terms pasisia (coastal), darek (land), and rantau are also known. The west of the Bukit Barisan area, which borders the Indonesian Ocean, is usually called pasisia. It is connected by pasisia, which is also the hilly plain of Bukit Barisan called darek. The area that includes river valleys and tributaries originating from the Bukit Barisan and empties into the Malacca Strait is called rantau. However, today the meaning of rantau has expanded to include areas outside of Minangkabau (Mansoer et al., 1970). 
Then, can the elements of Minangkabaunesse that appear in the film can be called Minangkabau aesthetic elements? In terms of aesthetics, this discussion relates to the concept of culture conveyed by Koentjaraningrat (1980) as a system of ideas, actions, and human works manifested as ideas, activities, and artifacts. That three forms states as systems that are closely related to each other. In this case, the most abstract design (idea) seems to be at the top to regulate the activities of a more concrete social system. In contrast, the activities in the social network produce material culture (artifacts).

Although trying to avoid it, I still meet the concept of differences in Western and Eastern in arranging Minangkabau aesthetic. Therefore, I chose the concept and understanding of Nusantara Aesthetics as a guide. The idea of the Nusantara's aesthetics in this discussion is in the sense of a series of aesthetic forms implemented through the language of symbols that were born from a search through natural suggestions (Kartika, 2010). Jakob Sumardjo (2010) added that the Indonesian nation's ancestors expressed teachings about the nature of things through symbols and metaphors because of their holistic and religious views. Symbols will be connotative, associative, suggestive, and lead to many interpretations. Symbols are an expressive way of thinking, which in turn can be reduced to logical reasoning.

On the other hand, the Minangkabau aesthetic construction that I try to build has a very close relationship with the Indonesian aesthetic concept by Kartika \& Perwira (2004). The concept of Indonesian aesthetics that is offered contains an orientation to the arts, the cultural system, and the religious' social system. Indonesian aesthetics with an art orientation symbolize vertical and horizontal relationships, namely the relationship between humans and their Gods, and human relations with other humans as a unitary social system. Its orientation to the cultural system brings meaning to the symbol of its attachment to belief in supernatural powers, which then materializes into artifacts that are considered cultural centers in specific eras. The cultural heritage of the age of animism and dynamism that tend to be mystical eventually merge into patterns and systems of religious life as a form of adaptation and acculturation of divine religious' beliefs.

The history of Minangkabau cannot be ruled out in building its aesthetic construction. Direct or indirect contact of a social group with the outside world will affect the behavior of individuals and groups. Some notes mention that Minangkabau is a very dynamic ethnicity in relation to outside influences. This dynamic (if we cannot call it conflict) mainly arises from the dualism of using matrilineal and patrilineal kinship systems. More precisely, there is tension between the customary social system and the Islam-based social system.

The entry of Islam to Minangkabau, which is believed taken place around the early 16th century (Hadler, 2008a; Nur, 1991), can be cited as an early marker of this tension. In addition to being called the largest matrilineal system actor in the world, the Minangkabau social system is unique, which combined with the patrilineal system (Azra, 2003; Dobbin, 2008; Graves, 2007; Hamka, 1984; Jong, 1980; Kahn, 1976; Kato, 1989). In the inheritance system, the Minangkabau uses matrilineal and patrilineal systems that involve property (pusako) and adat titles (sako). Inheritance of property is subject to a matrilineal system, where assets are inherited according to the maternal line, while customary titles are passed down according to the mamak line. However, both property and adat titles were still bequeathed to nephews. The combination of the matrilineal and patrilineal systems is thought to be the source of the dynamics and internal conflicts of the Minangkabau community (adat and Islam) and the growth and development of migrant behavior (Hadler, 2008b; Kato, 1989; Naim, 2013). The internal conflict in Minangkabau reflects the struggle to foster a harmonious social order and create harmony between the socio-cultural and religious aspects 
that appear to be always conflicting (Abdullah, 1966; Azra, 2003).

The Dutch colonial with their policies, also slowly changed the mindset of the Minangkabau people towards the kinship (suku) system into the nuclear family (batih) (Kato, 1978). BendaBeckmann (2000) mentions that when the tax system was implemented in 1908, the units responsible for paying taxes were groups that the Dutch considered a common harato pusako. For these groups, the Dutch coined the standard term, "kaum." Kaum were represented by a head, the Dutch called mamak kepala waris. The people with the harato pusako, together with mamak kepala waris become the standard legal entity. This condition then resulted in many mamak kepala waris committing fraud against the harato pusako they managed. Abdullah (2007) views the phenomenon of the Minangkabau people's restlessness in facing the Dutch colonial influence with their economic domination and efforts to adjust to the "new world." This condition occurred in the first two decades of the 20th century. Abdullah said this anxiety was the cause of the emergence of tensions between tradition and modernization, sustainability and change, and behavior in facing change. Graves (2007) highlights differences in the Minangkabau people's behavior due to the Dutch Colonial Government's influence in terms of education, which then gave rise to indigenous elite classes.

We cannot separate the recognition of rumah gadang as a Minangkabau icon from the Minangkabau aesthetic construction. According to its shape, rumah gadang is also commonly called rumah bagonjong because of the shape of the tapered roof soaring (Navis, 1984). Rumah gadang, for the Minangkabau community, is not merely a place for a family residence. Rumah gadang is a symbol of the presence of one people in one village and a center of life and harmony, such as a place for community family consensus and carrying out ceremonies (Navis, 1984; Prasetya \& Adi, 2011). Franzia et al. (2015) added that the architecture, construction, decoration, and function of the rumah gadang reflect Minangkabau's culture and values. Rumah gadang is a residence, a meeting place for relatives, and also used as a place for traditional ceremonies. The ownership of rumah gadang rests with the women who live there and is passed on to the girls. According to Minangkabau adat, a person's primary affiliation is to the rumah gadang and suku.

The Minangkabau aesthetic construction concept can also be compared with the Asian aesthetic in the film proposed by Pugsley (2013), which aligns with Chinese and Japanese aesthetic ideas. Pugsley concluded that aesthetic concepts do not exist in isolation. Aesthetic appreciation is a pragmatic form of social governance. The point is how to develop philosophical thinking (East) with a logical mindset (West) and apply it to local culture. The understanding that "beauty" is in the level of ideas, images, and subjective ideas will be objective and recognizable. It can be understood through actual images, which can be seen as the starting point for building aesthetic constructions in art.

It seems that the Nusantara aesthetic concept can be used as a basis for building the foundation of the Minangkabau aesthetic concept. The combination of macrocosm and microcosm world in the Nusantara aesthetic concept in the Minangkabau community appears in the form of a combination of adat and Islam. A search of Minangkabau aesthetic studies in several works of art: dance (Efrida, 2016; Rustiyanti et al., 2013), music (Fulzi, 2011), carving (Efrizal, 2010), and traditional clothing (Maresa, 2009) shows a tendency towards the same concept. Minangkabau aesthetic elements in some of these works of art show the close relationship between human behavior towards nature, both dealing with, cultivating, and utilizing nature. Furthermore, it can be said that the wisdom of this behavior is a manifestation of human submission and gratitude to God. These three elements - man, nature, God then differentiate Eastern and Western aesthetics. Minangkabau aesthetics concretize it with alam 
takambang jadi guru 'nature as teacher', tungku nan tigo sajarangan 'furnace with three fireplaces', tali nan tigo sapilin 'rope with three strands', and emphasized by adat basandi syarak, syarak basandi Kitabullah. This concept is the basis for the Minangkabau aesthetic construction in this study.

Minangkabau is a cultural area that transcends geographic boundaries. The behavior of migrating the Minangkabau community is believed to be one reason for expanding the limitations of this cultural area. Not surprisingly, when it comes to film as an industrial product, the discussion of Minangkabau aesthetics in the film also touches on the realm of national culture, Indonesia. Although it also brings problems, the term trans ethnic is considered most appropriate in this discussion. The inter-ethnic contact that appears in the film is also a manifestation of an understanding of ethnic identity. The assumption of differentiation in terms of ethnicity will lead to equality as the builder of nationality. Therefore, I realize that building an aesthetic concept of ethnicity will have very fragile results. However, the building is expected to cover Minangkabau's uniqueness as a differentiator from other ethnic groups in Indonesia which also have it.

\section{Method}

Exploration sources in this article are films that are assumed to show Minangkabau content, namely Harimau Tjampa (1953, dir. D. Djadjakusuma), Salah Asuhan (1972, dir. Asrul Sani), Merantau (2009, dir. Gareth Evans), Di Bawah Lindungan Ka'bah (2011, dir. Hanny R. Saputra), Tenggelamnya Kapal van Der Wijck (2013, dir. Sunil Soraya), dan Surau dan Silek (2017, dir. Arief Malin Mudo).

Because the data sources are film, mise en scene becomes an analytical tool to find visual images that indicate Minangkabaunesse elements. Mise en scene analysis is used because the cinema, which is in the image's form, is the creator expression product. Shots cannot be separated from this discussion because the visual images, as a result, can construct meaning both relational and independent. The focus of exploring the Minangkabaunesse elements in this discussion is traditional colors, actors' appearance, and subjects in visual images. Pugsley (2013) states that visual images' subject is physical appearance, whether who or what appears and appears in the images. Meanwhile, Lukinbeal (2005) states that in film, landscapes are a geographical metaphor because they provide meaning to explore the relationship between narrative and geography. In this case, the landscape can exist as a place, space, or metaphor.

Apart from being seen as a representation, landscapes are closely related to the story setting even though they both contain different meanings. On the other hand, characterizations built through the dialogue and acting of actors are also a consideration in compiling this Minangkabau aesthetic construction. Therefore, the Minangkabau language in dialogue is also a material for studying the possibility of the emergence of the Minangkabau ethnic identity discourse. The expressive aspect (auteur) was deliberately not the focus of this discussion, although it did not rule out the director's background. In short, the director's style of creation is not a consideration in this discussion. The source films of this study are treated independently as a collaborative product (Thomson-Jones, 2008). Also, this discussion pays attention to Adorno \& Horkheimer (1993), who explained about how art becomes a product of the cultural industry. In the cultural industry, art's authenticity is only seen as a general uniformity that voices the dominant group. Art is seen as romanticism and a dream of the past.

\section{Minangkabau Aesthetics in Film}

In this discussion, the Minangkabau aesthetic construction preparation in the film cannot remove the consideration of the concept of Indonesia as a national culture. Heider (1991) states that Indonesian movies are not regional but 
national. In this case, Heider considers the use of Indonesian with some restricted vocabulary in the dialogue. He concluded that these characteristics are the characteristics of "national films," although he admits that many films raise regional culture aspects.

Heider's statement indirectly has gaps like locality in Indonesian films. The choice of setting - both spatial, time, and social - and local language vocabulary shows the aesthetic representation of locality as content in Indonesian films. The use of Indonesian in the Minangkabau film can be seen as an effort to build nationality. In the end, searching for Minangkabau aesthetics not only find the Minangkabau content but also identified it based on the concept of Nusantara aesthetics, which has local Minangkabau colors. Apart from industrial content and encouragement, Indonesian is a form of recognition of pride and nationalism.

\section{Landscape and Building}

One thing to note, there is a difference in understanding between the narrative setting and the landscape. Setting refers to the place or location of events and stories, while landscapes contain a more complex meaning (Lefebvre, 2006). According to Lukinbeal (2005), the landscape is an eye-catching building in the film because it provides materials for exploring the intersection between geography and narrative. The landscape in the film is a representation. In this case, Lukinbeal categorizes them into landscapes as spaces, referring to certain places, as spectacles, and as metaphors. Landscapes that refer to specific places show geographical aspects and localities that have been widely recognized by the audience. Pugsley (2013) emphasized that text localization emerged through landscapes as an aesthetic device in a film.

The visual images that are most easily recognized as elements of continuity are buildings and landscapes. Rumah gadang and rangkiang with gonjong roofs are the most easily recognizable Minangkabau icons. The adaptation in the art of architecture has made this gonjong roof more widely known during its development. On the other hand, the gonjong roof is no longer a feature of the rumah gadang or rangkiang but has become a Minangkabau ethnicity feature. That is shown through the gonjong shape on the modern building roof and even a logo and emblem design.

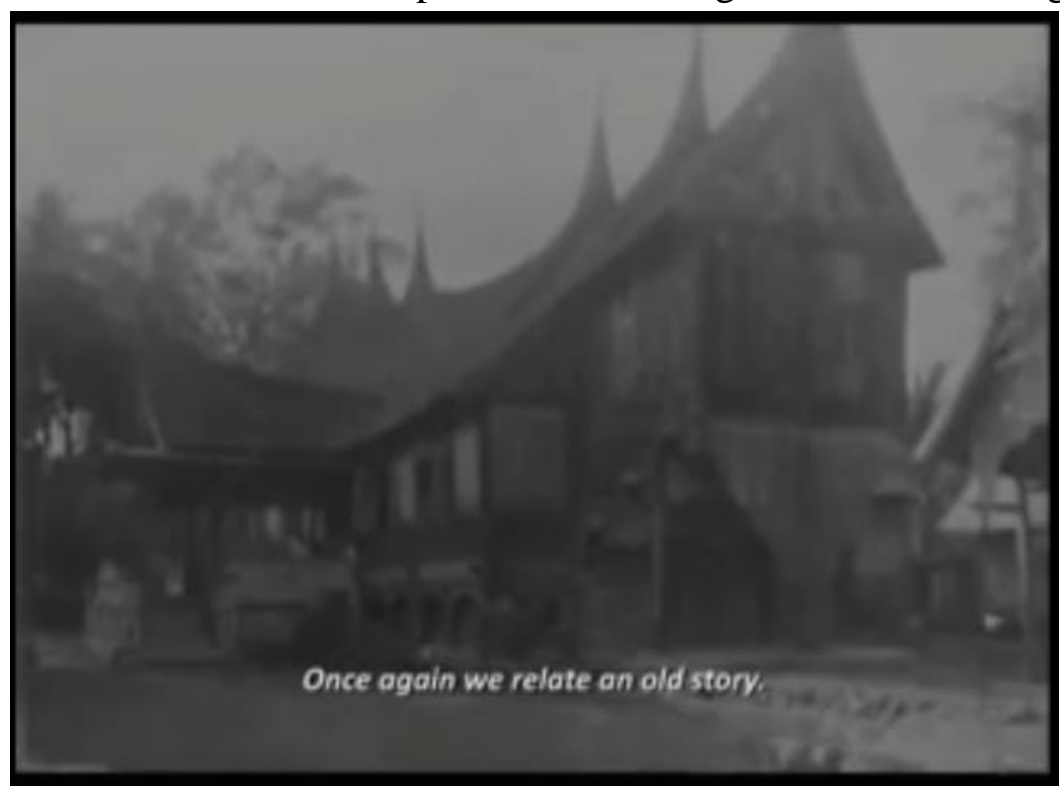

Figure 1. Rumah gadang.

Still from Harimau Tjampa. 


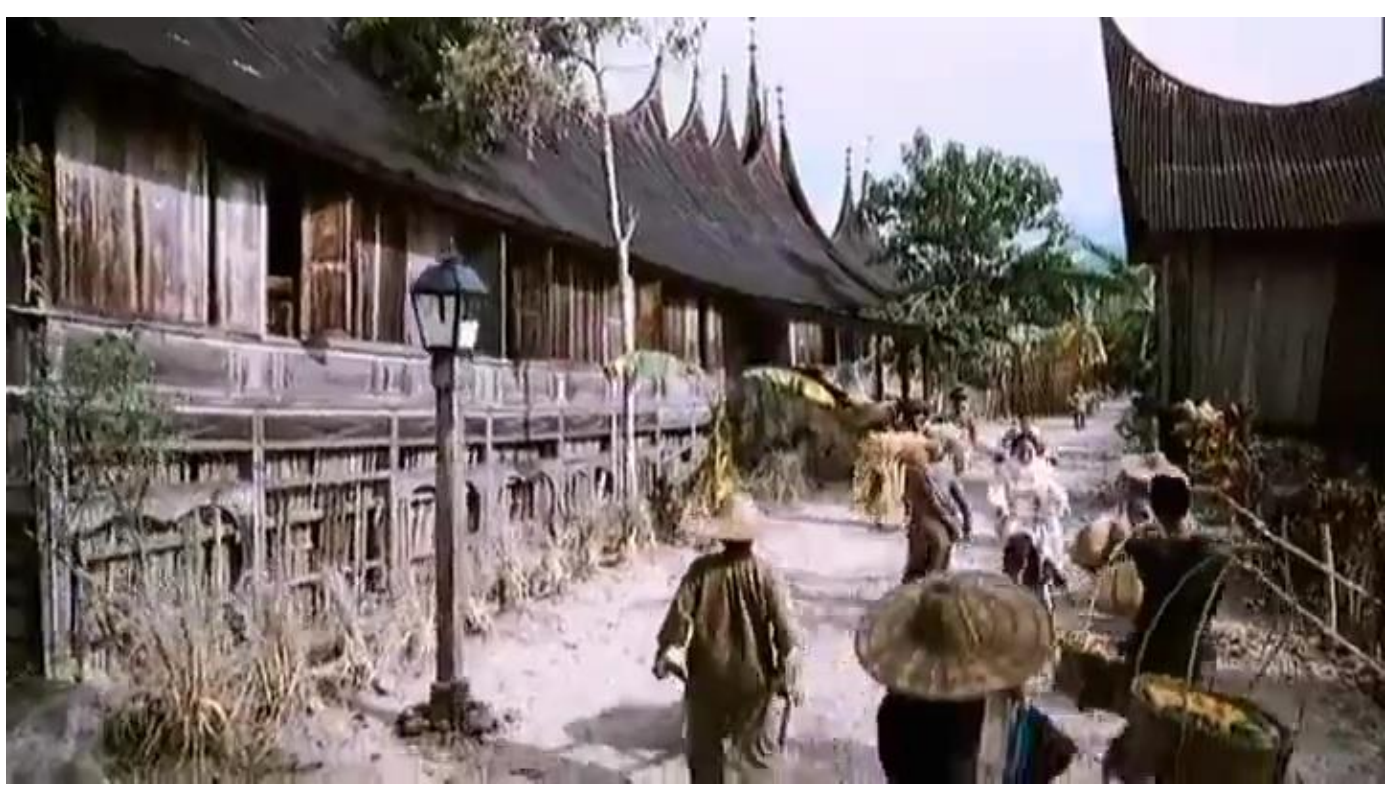

Figure 2. Rumah gadang.

Still from Di Bawah Lindungan Ka'bah.

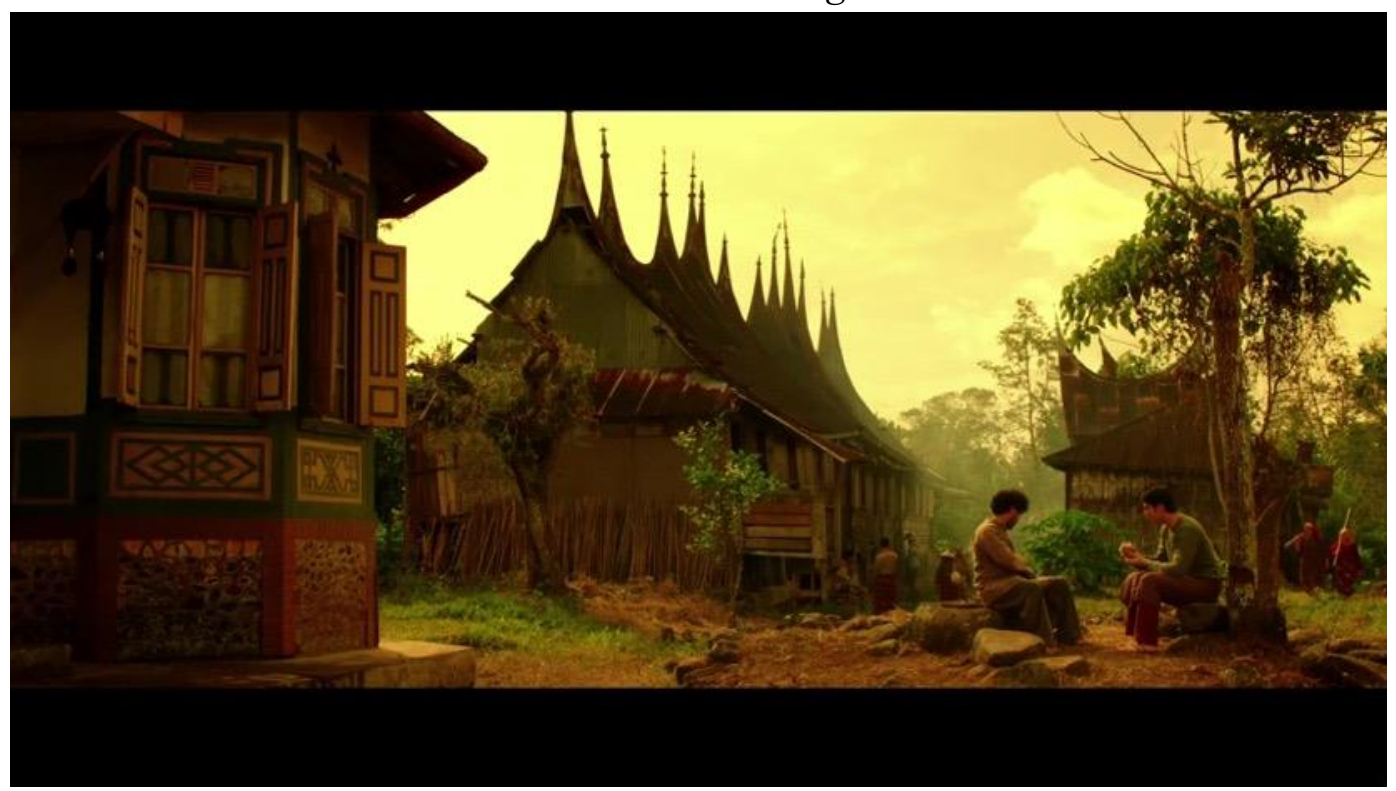

Figure 3. Rumah gadang as landscape.

Still from Tenggelamnya Kapal van Der Wijck.

For the Minangkabau community, rumah gadang is not merely a family residence. Rumah gadang is a symbol of someone presence in one village, as well as a center of life and harmony, such as a place for family consensus and carrying out ceremonies (Bahauddin et al., 2012; Navis, 1984; Prasetya et al., 2011). Rumah gadang has a unique shape. The roof is tapered and resembles a buffalo horn (Kato, 1978). This buffalo horn shape is often associated with the Minangkabau victory's folklore during the invasion of the Javanese kingdom to Sumatra (Franzia, 2017).
On the other hand, the gonjong shapes that resemble buffalo horns that rise upwards are believed to symbolize the human relationship with God (Franzia, 2017). In brief, it can be said that the main characteristic of a rumah gadang is visually a gonjong roof that resembles a buffalo horn. It also seems to be emphasized in the Harimau Tjampa through the visual image of the gonjong roof (Figure 1). Several scenes in $D i$ Bawah Lindungan Ka'bah and Tenggelamnya Kapal van Der Wijck show the dominance of the rumah gadang, both as a residence and as a social space (Figure 2). The appearance of the rumah 
gadang in the film can be described as a representation of the Minangkabaunesse. In this case, the rumah gadang appears as a background, space, and a symbol of the Minangkabau aesthetic.

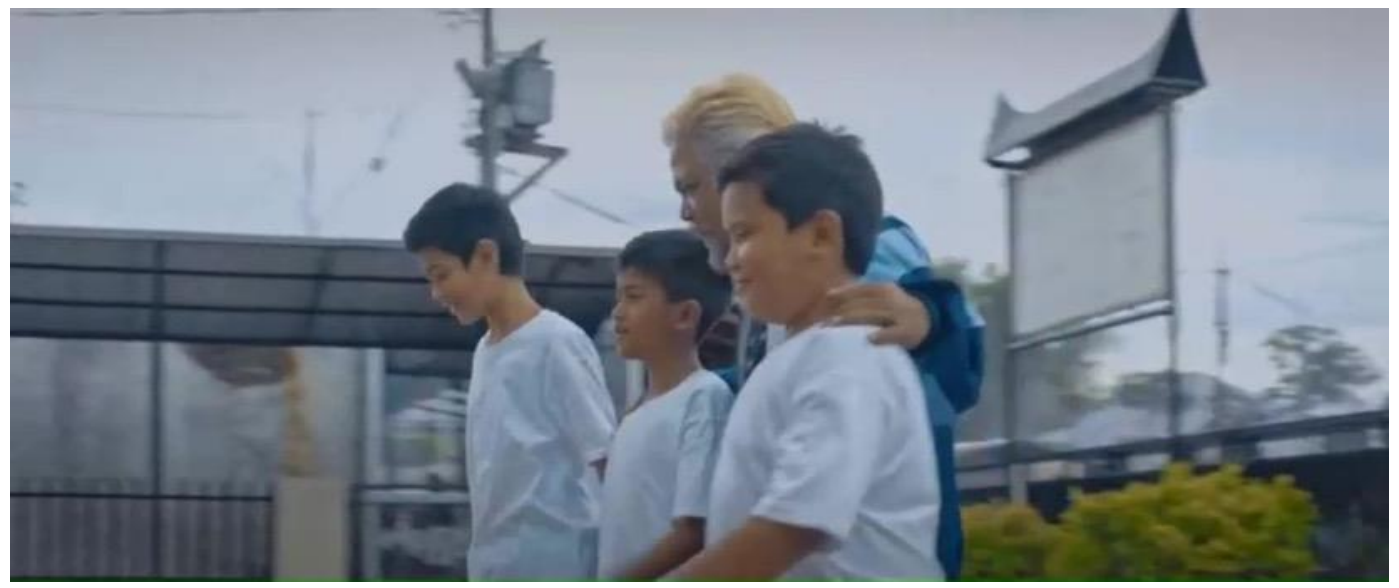

Figure 4. Gonjong as a signboard ornament.

Still from Surau dan Silek.

The landmark of Bukittinggi, Jam Gadang, emphasizes the social and social setting in the Surau dan Silek (Figure 5). Suppose it is related to the development of architectural arts. In that case, the representation of identity through this building form indirectly shows the Minangkabau people's loyalty to their traditions and culture. This characteristic of the gonjong roof is then adapted into visual forms that tend to be stereotypical, such as symbols, logos, or icons that have a gonjong shape (Couto, 2008; Soenarto \&
Sudyarto, 1983). The gonjong shape, to fulfill identity and function, was eventually modified partly or wholly in modern buildings. In general, the gonjong shape is transformed by taking a curved, pointed roof and the tilt angle. As a regional identity, the roofs of residential houses, offices, and public facility buildings are also made as gonjong of rumah gadang (Azmi \& Pane, 2018; Ralie et al., 2019). This form appears in the Surau and Silek as a decorative ornament of a signboard

(Figure

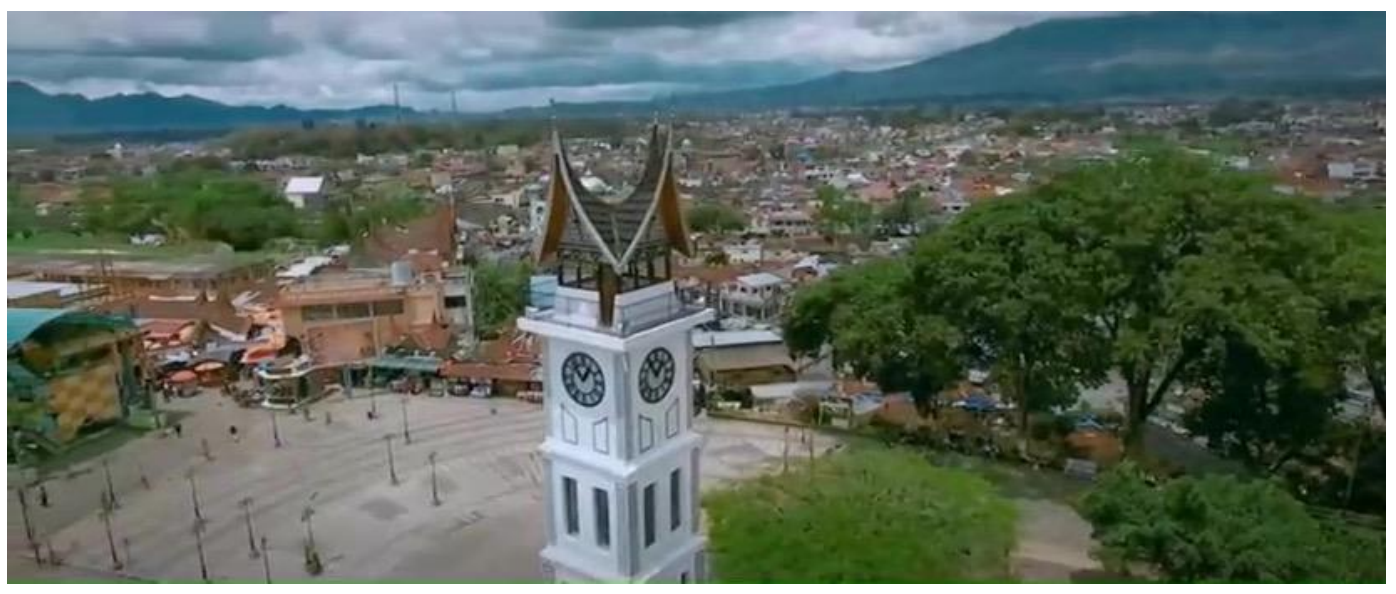

Figure 5. Jam Gadang Bukittinggi, landmark as landscape.

Still from Surau dan Silek. 


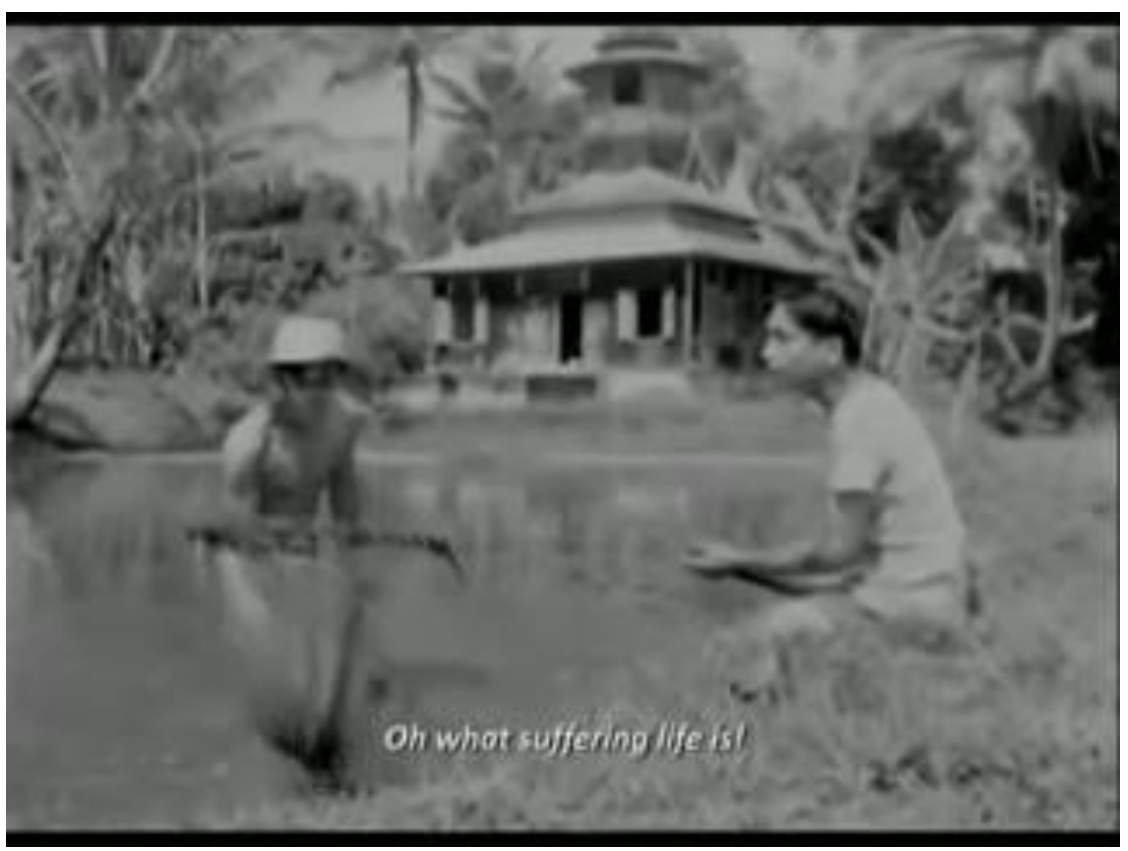

Figure 6. Surau in landscape.

Still from Harimau Tjampa.

The appearance of tropical nature in several films indirectly shows the landscape and represents the Nusantara aesthetic. In particular, the aesthetic refers to Minangkabau when

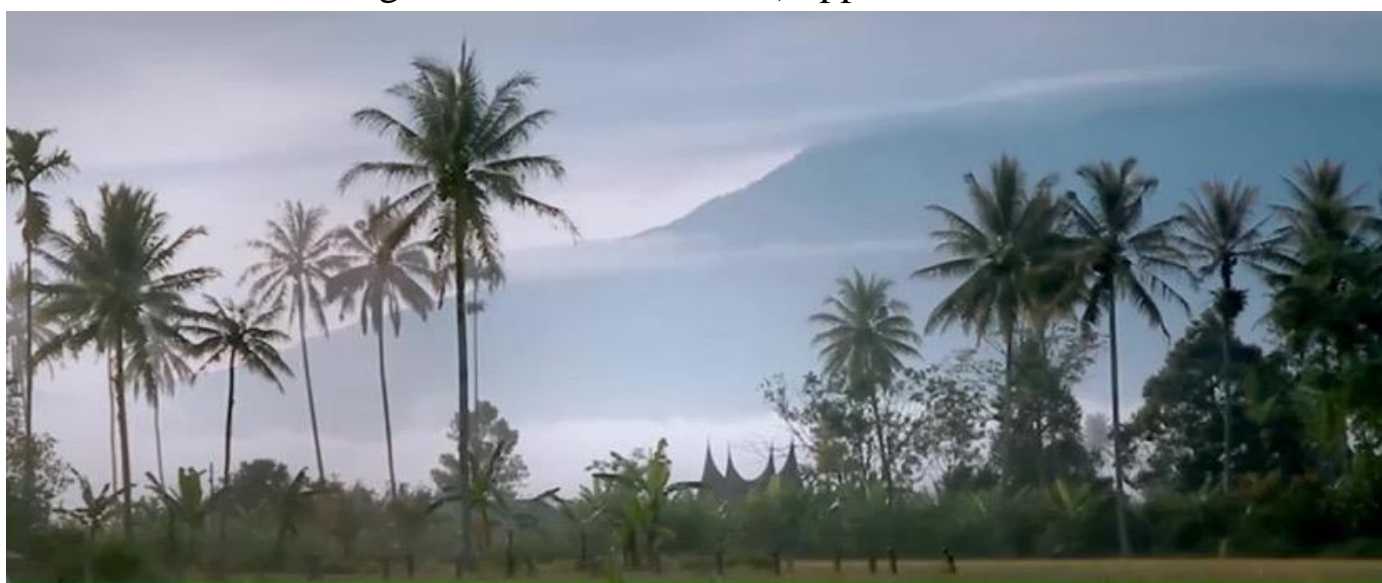

Figure 7. Gonjong in landscape.

Still from Surau dan Silek.

For the Minangkabau people, especially men, surau and lapau cannot be separated from the journey of life either as individuals or social groups. Concerning the position and role of men in Minangkabau, surau is a place to meet, gather, and sleep for boys who have reached maturity and who are aged. Surau is a traditional educational institution in Minangkabau. In surau, Minangkabau youth explore and increase knowledge about Islamic customs and religions. In its later development, there was a separation of connected with an icon. In Harimau Tjampa, rice fields with a surau as a background (Figure 6) and plantation landscapes with gonjong roofs (Figure 7) appear in Surau and Silek. 
welfare of the surau, students have responsibilities towards the teacher (shaykh) and the environment around the surau. Added by Azra (2003), because students are not asked for tuition fees, food and lodging fees, or any financial responsibility, students must help their shaykh or teacher in gardens or rice fields, which are generally donated people around the surau. This image appears in a scene in Harimau Tjampa (Figure 6). Even though it is displayed differently, surau in Harimau Tjampa and Surau dan Silek is shown in the function of a place to study Islam and Minangkabaunesse, in this case, silek.

At the beginning scene, the Harimau Tjampa shows a visualization of lapau (Figure 8). In this event, Lukman received information about Datuk Langit as a warrior and the Head of Nagari. In Surau dan Silek, lapau also appears as a means of communication between youths. In this lapau, Rustam received information about his friends who had succeeded overseas, so he also decided to go abroad (Figure 9).

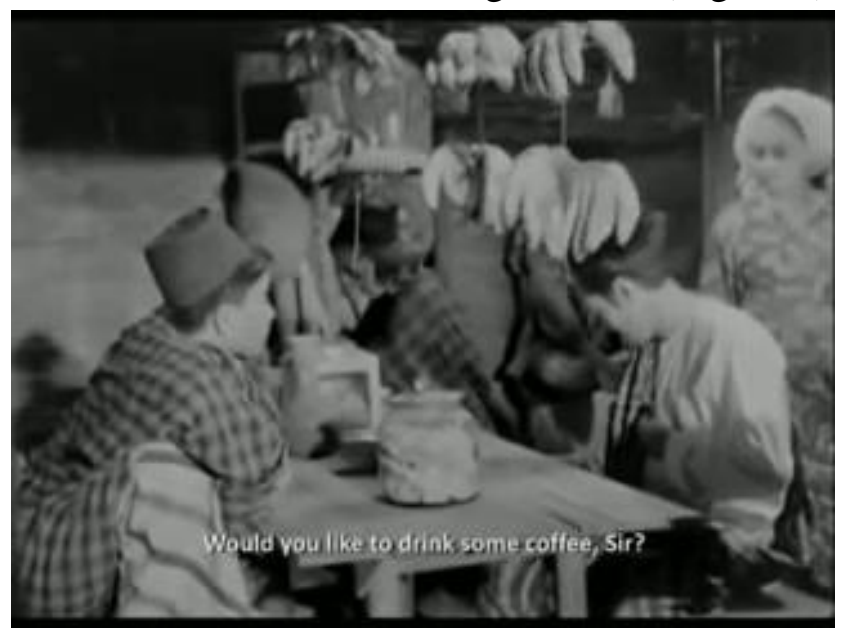

Figure 8. Lapau.

Still from Harimau Tjampa.

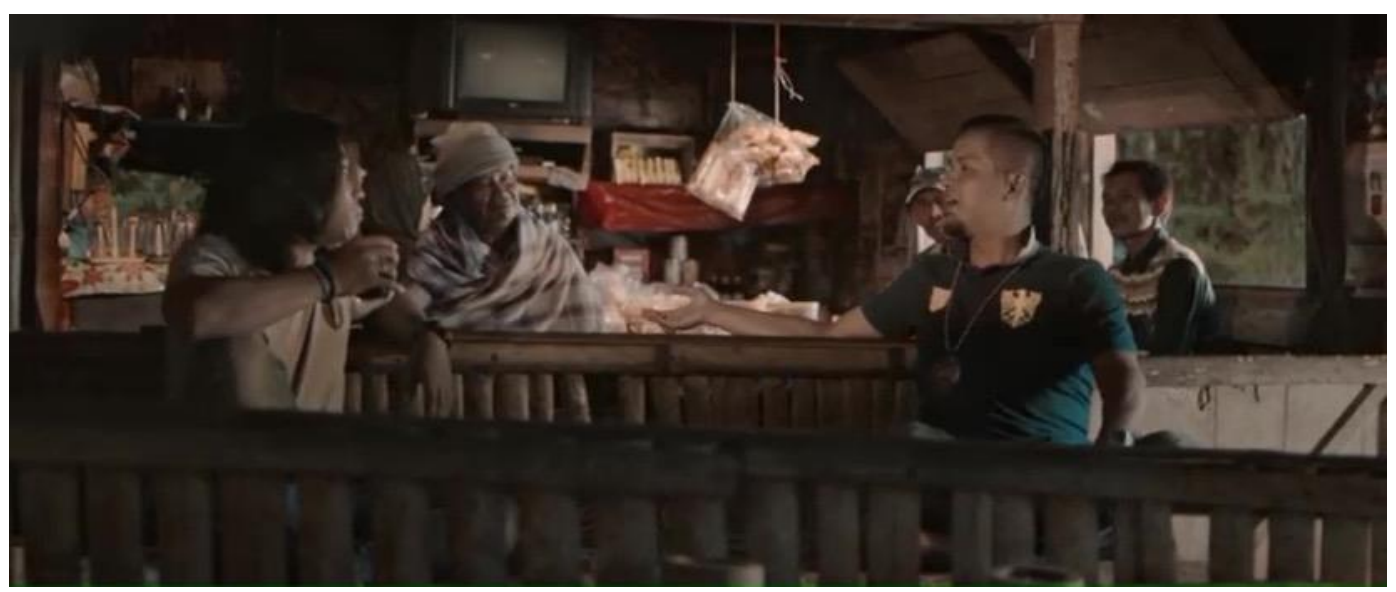

Figure 9. Lapau.

Still from Surau dan Silek.

Lapau is the name of a shop that sells food and drinks. In addition to the surau and balai adat, lapau is also a social institution for the Minangkabau community to develop an open and dialogical attitude (Fadhil, 2008), as a forum for communication village community members, especially men (Nain et al., 1988). This behavior grows as a form of escape from the Minangkabau custom, which does not provide space for men in rumah gadang (Kato, 1978; Naim, 2013). On the other hand, through this surau and lapau, Minangkabau youth learn about life and life, especially for the provision of married life (Hadler, 2008b). Lapau for the Minangkabau is 
not just a place to eat and drink. Lapau is a place for free expression, communication, and information.

The choice of buildings and landscapes seems to be an alternative to building progressive content and the stereotypical concepts that are already familiar to the audience. In the end, buildings and landscapes help build the narrative and emphasize the meaning side by side with the events in the story. On the other hand, shooting techniques also helped build Minangkabau's aesthetic construction. Extreme long shots, long shots, and deep focus techniques, even bird's-eye view, are commonly used to depict these buildings and landscapes. The repetition of Minangkabau buildings and landscapes' images seems to emphasize the structure and relationship of the narrative with social and social settings as Minangkabau aesthetic constructions in the film.

\section{Tradition}

In terms of language usage, the use of Minangkabau language in character dialogue can be said to be an attempt to maintain the Minangkabau 'taste'. The practice of translating regional languages is believed to be insufficient to represent the meaning. Harimau Tjampa, as a whole, uses Indonesian language in the dialogue. It can be said, Harimau Tjampa lost the Minangkabau 'taste' even though the background was built as Minangkabau. It is not surprising that Hanan (2017) said Harimau Tjampa did not describe the ideal Minangkabau.
In his study of the Harimau Tjampa, Hanan (2017) said that Minangkabau was described differently and not ideal. Hanan highlighted the appearance of power and domination of one group over another. In this case, Datuk Langit, as the antagonist, represented the power under the Dutch colonial influence over Saleh and Lukman's figures, the protagonist representing the second class society. Although this opinion is not wrong, if it is related to the story's time setting, the picture is a representation of the change in mindset and social system that occurred in Minangkabau at that time. Through adat groups, the Dutch colonialists tried to control and dominate Minangkabau by forming a new government system based on adat (BendaBeckmann, 2000; Hadler, 2008b).

In the story, Saleh in Harimau Tjampa is built as a character who teaches in surau. It implies that Saleh has mastered the knowledge of Islam and adat. He conveyed Saleh's considerations in accepting Lukman as his student with pantun and pepatah petitih 'proverb'. The mastery of langkah nan ampek 'the four steps' as the basis shows that the philosophy of silek as self-defense is not a means of fighting but rather defends justice, musuah indak dicari, basuo pantang diilakkan. The first three steps in a practical action are defense as a form of patience against the opponent's attacks. Even though the fourth move seems like an attack, the physical one is to push the opponent away (Figure 10). 


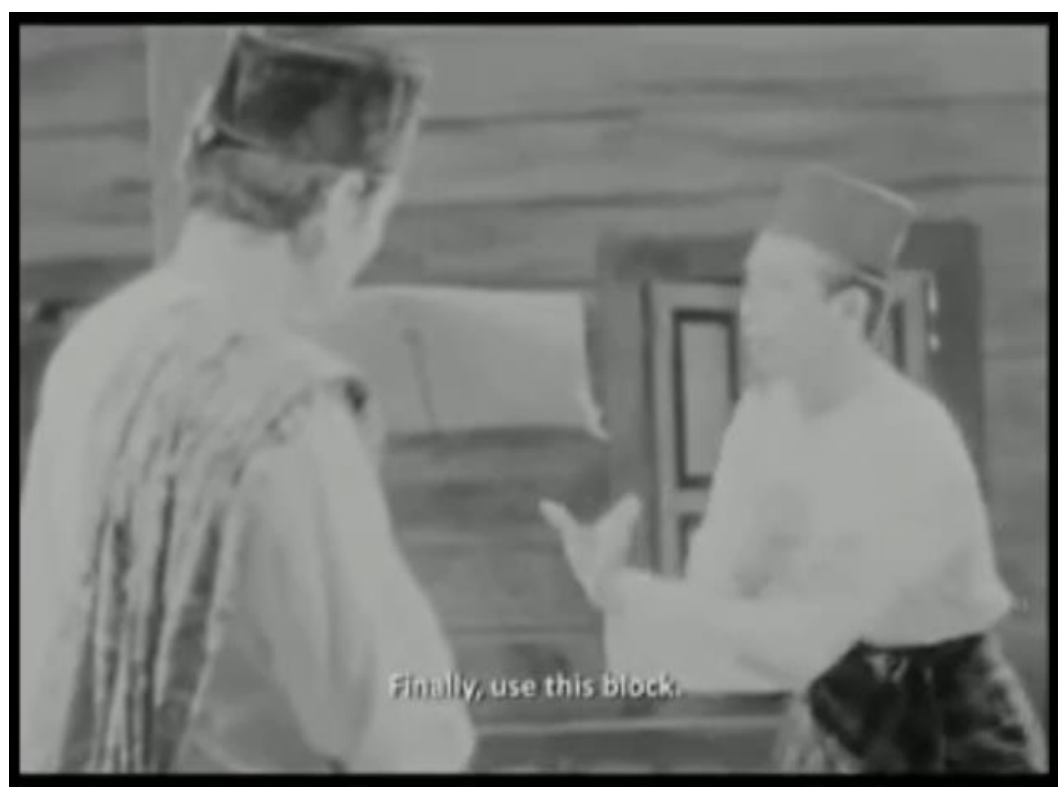

Figure 10. Final step in silek.

Still from Harimau Tjampa.

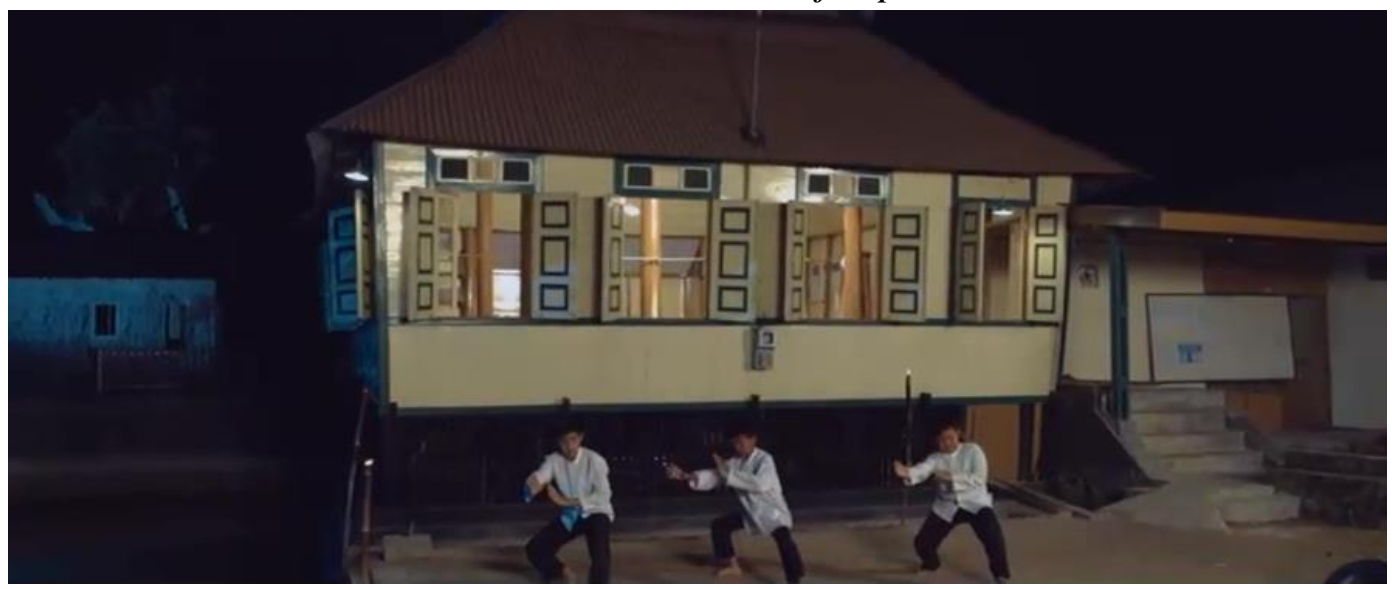

Figure 11. Adil, Kurip, and Dayat are practicing silek in the surau yard.

Still from Surau dan Silek.

This silek philosophy also appears in the film Surau dan Silek through the character Johar while practicing silek Adil, Kurip, and Dayat. Basilek for the Minangkabau means fostering human relations. Through Johar, the Minangkabau silek is described as the embodiment of amar ma'ruf nahi munkar. In silek, there is also the philosophy of lahia mancari kawan, batin mancari Tuhan. Therefore, for the Minangkabau people, silek cannot be separated from surau.

One thing that is interesting in Surau dan Silek is that this film shows the conflict between two silek generations in Minangkabau. On the one hand, the older generation represented by Johar considered silek a legacy of the Minangkabau tradition with Islamic elements because it was obtained in the surau. Johar considers silek as a martial skill, not for a fight. Minangkabau silek is described as the embodiment of amar ma'ruf nahi munkar because there is a connection between salat, salawat, and silek. In silek, there is also the philosophy of lahia mancari kawan, batin mancari Tuhan 'outer looking for friends, mind seeking God'. On the other hand, the younger generation represented by Adit, Kurip, and Dayat represents efforts to preserve the silek tradition. In this case, the three figures make it happen through silek tournaments. The hope is that silek will be better known regionally, nationally, and globally. 


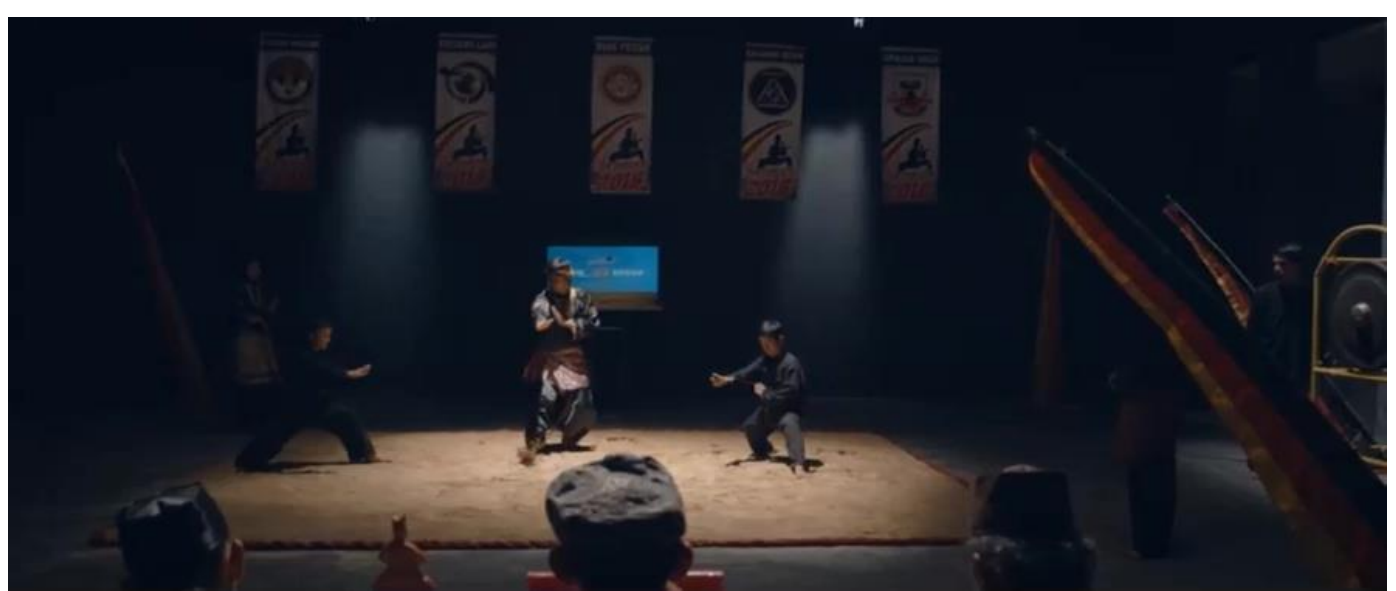

Figure 12. Silek as tournament.

Still from Surau dan Silek.

Minangkabau people also gather, socialize, and exchange information at an event. This event is known as Alek Nagari 'people's party'. From various kinds of Alek Nagari, pacu kudo 'horse racing' and buru babi 'pig hunting' appear in Harimau Tjampa and Tenggelamnya Kapal van Der Wijck. Its believed that Minangkabau people carry out pacu kudo before the Dutch colonial entry to West Sumatra. The Minangkabau aristocratic elite carries out pacu kudo in the context of celebration or just entertainment (Farid \& Fatimah, 2019). This horse race was also carried out to choose the king's son-in-law during the Pagaruyung kingdom reign. In its development, pacu kudo has become part of Alek
Nagari in several Minangkabau areas (Anwar et al., 2013).

For some Minangkabau people, buru babi is considered a form of social negotiation over the matrilineal system's dominance. This social practice that emphasizes the aroma of masculinity and physical strength is created, hoping that the scent of femininity will be marginalized. In several Minangkabau areas, this activity has been legitimized as an adat activity (Arifin, 2012). On the other hand, this pig hunting activity can be related to agricultural production and products. Pigs are considered a nuisance and need to be eliminated. Buru babi can be regarded as the Minangkabau people's effort to maintain balance and natural ecosystems.

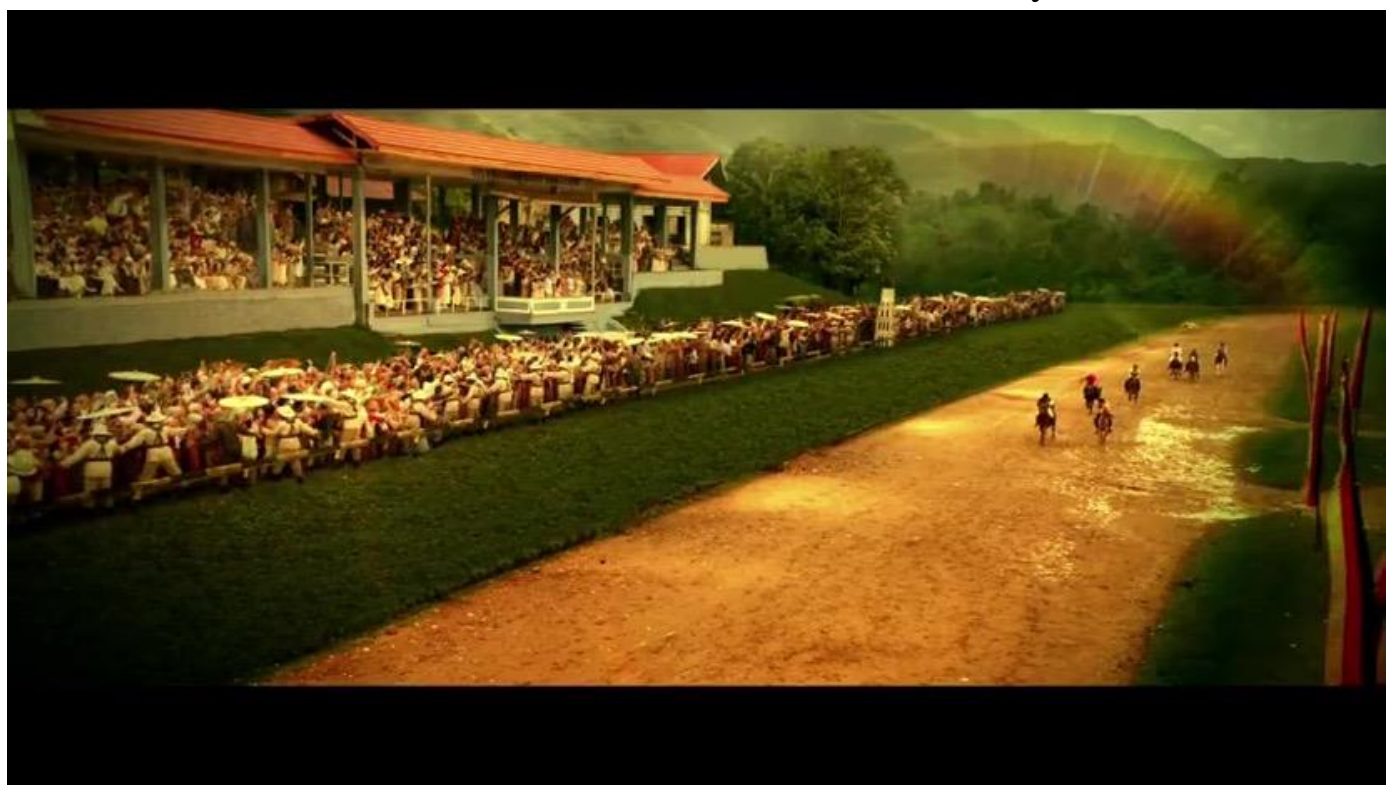

Figure 13. Раси kudo 'horse race'.

Still from Tenggelamnya Kapal van Der Wijck. 
In Minangkabau social institutions, mamak have a vital role both in family, relatives, and suku. Mamak is mother's brother. According to Navis, mamak are also leaders. Therefore, mamak also means that the younger see, the older as of the leader (Navis, 1984). Following their functions and duties in the Minangkabau matrilineal kinship, there are mamak rumah, mamak suku, and mamak kaum. The task of the mamak rumah is to care for, build, and lead the life and physical and spiritual happiness of her nieces (Mansoer et al., 1970). In terms of the marriage of her nephew, the mamak has a vital role. Even if a mamak does not play a role in matchmaking, a mamak's permission and blessing are a must (Kato, 1978). Graves (2007) added that mamak would take full responsibility for her sister's child if the father cannot support the child, has died, or has divorced his wife.

The duties, roles, and positions of the mamak are among the centers of criticism in Salah Asuhan. Hanafi rejects mamak intervention in his personal life. Whereas in the Minangkabau social system, mamak is responsible for their nephews. Besides, the respect of the young to the old is absolute. The role and obligations of Sutan Batuah as a mamak have been fulfilled through his assistance to finance Hanafi's education. Hanafi is a representation of changes in the social system in Minangkabau by the Dutch colonial influence. Due to the effect of Western education, Hanafi rejected Minangkabau's customs and traditions. The duties and obligations of mamak as relative were seen as an interference that he did not need. However, at the end of the story, Hanafi's return becomes a symbol of his adat submission. Indirectly, Hanafi's behavior recognizes the Minangkabau custom, which is indak lapuak dek hujan, indak lakang dek paneh 'not weathered by rain, not cracked by heat'.

Besides, Sutan Batuah and Hanafi's mother's intention to pair him with Rapiah reflects the understanding of the Minangkabau people's ideal marriage. According to Minangkabau people's mind, the ideal marriage is between a close family, such as a marriage between a child and a nephew. Such a marriage is commonly referred to as pulang ka mamak and pulang ka bako. Pulang ka mamak means marrying mamak child while pulang ka bako means marrying the father's nephew (Asmaniar, 2018; Graves, 2007; Navis, 1984). The closer the kinship is, the stronger the marital relationship will be. It is shown through the match between Hanafi and Rapiah, who is Sutan Batuah daughter, Hanafi's mamak.

The role and duties of the mamak to maintain and develop the property also appear in Di Bawah Lindungan Ka'bah. Rustam matches his nephew Zainab with his other nephew, Arifin. In this case, Arifin, who is undergoing an arranged marriage, pulang ka mamak. It was clearly and verbally conveyed that the match was to protect the inheritance of Engku Jafar, Zainab's father. According to Navis (1984), this marriage mode is more like preserving the husband and wife relationship. It is not disturbed by problems that arise because both parties' relatives' interference is a negative excess in inheriting property. In the matchmaking, Rustam shows the role of the mamak in the matchmaking of his nephew. The role of the mamak also appears in Tenggelamnya Kapal van Der Wijck. The choice of Azis as Hayati's future husband shows the mamak's duty and obligation to defend and elevate the dignity of his suku. The duties and roles of mamak towards nephews, especially girls, prepare for welcoming warih bajawek and preparation for a continuing generation. Warih Bajawek means the focal point of the community at home with the role of a grandmother and a mother who will take care of their children and grandchildren and as a wife who becomes a link with other communities (Navis, 1984). In this case, by mamak Hayati, Azis is seen as a respected family that can elevate his suku's social status. 


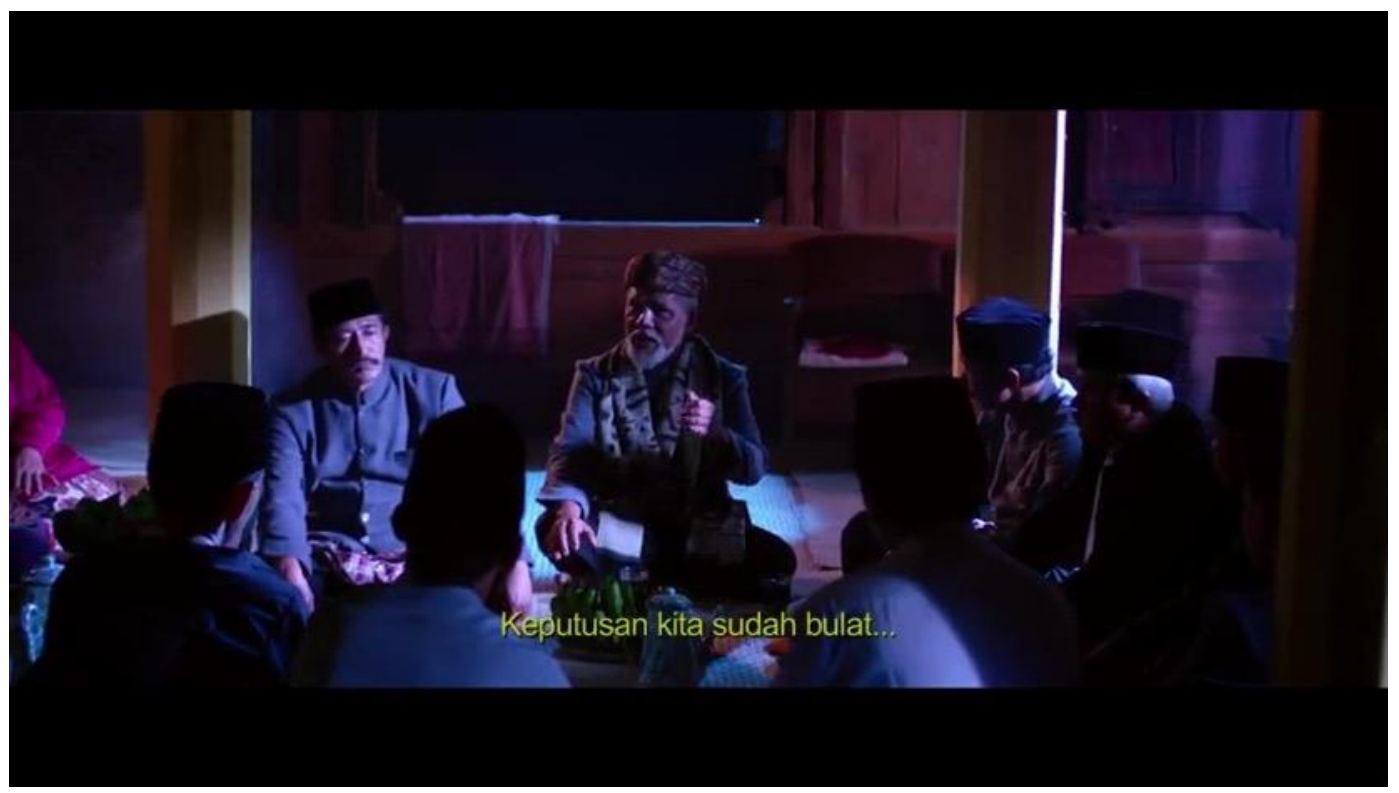

Figure 14. Deliberation of ninik mamak.

Still from Tenggelamnya Kapal van Der Wijck.

Marantau (migration) also cannot be separated from the effort to build Minangkabau's aesthetic construction in film. Marantau for the Minangkabau people can not only be seen as the behavior of leaving their hometown in search of a better life. This behavior also shows the Minangkabau people's attitude, especially men, in facing their life conditions, both personal and social. It is because Minangkabau boys have been pushed to leave the house from a young age. Minangkabau boys are not given special accommodation in the rumah gadang like girls. They were told to sleep in surau to learn and prepare for life (Kato, 1978; Naim, 2013; Warokka, 2020). Of course, this condition is related to the matrilineal kinship system of the Minangkabau people.

Kato (1978) states that migrating activities are related to the Minangkabau social dynamics that show a flexible and conservative nature. In connection with the reasons for migrating, Naim (2013) concluded that there are five factors for the Minangkabau people to leave. First, physical characteristics, namely ecology and location. Second, economic and demographic factors. Third, the educational aspect. Fourth, the city attraction. Fifth, political unrest. This fifth factor is limited to the period of 1926-1927 during the communist rebellion. The peak was in 1958-1960 during the PRRI rebellion. During that period, it was admitted that there had never been a Minangkabau population (West Sumatra) leaving their village in such a large number. Indirectly, Naim's motive for migrating Minangkabau people also shows the social changes that have taken place in Minangkabau.

This marantau behavior appeared differently in each discussion subject. The concept of marantau dakek emerged through its characters in Harimau Tjampa by Lukman, Di Bawah Lindungan Ka'bah by Hamid, and Tenggelamnya Kapal an Der Wijck by Zainuddin. The motives of the three also show similarities, namely, the educational reason. Through different time settings, the three films present other motives and prevailing social systems. Lukman's character represents classic migrant behavior, studying (silek) for revenge. Meanwhile, Hamid and Zainuddin's figures show migrant behavior influenced by the cultural influences brought by the Dutch Colonial. Hamid and Zainuddin are representations of a migrant with educational motives that contain the goal of a better life, especially in terms of economics.

The concept of marantau jauah (outside West Sumatra) emerged through the character Zainuddin in Tenggelamnya Kapal Van Der Wijck and figures Johar and Rustam in Surau dan Silek. All three carry the same motive, namely a better life. Also, Johar's character represents an ideal 
perantau (migrants), who returning to their hometown to spend their old age. Apart from letting go of longing, at least to bury in the birth land. According to Navis (Navis, 1984), it is an insult to all people if they let their citizens die and bury them overseas. There are two aspects that they want in this regard, a heart which is always attached to the village from which their ancestors came. Another reason is due to practical reasons. There is a close family member who will care for and take care of their old age. The hope is that they die in the presence of relatives and are buried in homeland.

Graves said that perantau from Minangkabau would return to their hometowns and stay permanently after their title or title was promoted (Graves, 2007). In this case, Maude said that Minangkabau migrants, who returned to their hometowns, were dominated by civil servants who had retired (Maude, 1979). It appears through the character Johar in Surau dan Silek. This figure is described as a retired lecturer who returned to his hometown to spend his old age. On the other hand, a different thing in perantau behavior appears through the character Rustam in Surau dan Silek. Rustam's intention to leave was caused by the shame of living in his hometown without a permanent job. He compared his life in the village with his friends who had migrated and were successful overseas. A different motive for merantau also emerged through the character Hamid in Di Bawah Lindungan Ka'bah. Hamid left his hometown to wander because he was disappointed at not marrying Zainab even though he was verbally stated to deepen his knowledge.

\section{Conclusions}

The choice of stereotypical imagery in a film does not appear to be coincidental. The appearance of the visual image of the rumah gadang and the gonjong roofs seems to be a marker of continuity. However, it is not always true when connected with the understanding of the setting and the landscape. The recognition of visual icons by the audience, in an industrial context, aims to attract them as an audience. On the other hand, the tourism industry is also affected by the beautiful landscape shown in the film. In the end, in the cultural industry context, content is transformed into material that is deliberately manipulated and presented to the audience for consumption.

It is not easy to construct an aesthetic construction of ethnicity. In this case, the Minangkabau aesthetic in Indonesian films is constructed by many elements, both material and non-material. The hope is that the Minangkabau aesthetic construction, especially the one in the film, can be a minimum measure of differentiating the continuity content. Not all Minangkabau content, whether culture, tradition, even language, can be called Minangkabau so that the audience is no longer entangled with excessive chauvinism of their ethnic identity. Of course, the relationship with narrative elements is a significant consideration and the stereotypical constructs that are well known.

\section{Reference}

[1] Abdullah, T. (1966). Adat and Islam: An Examination of Conflict in Minangkabau. Indonesia, 2 ,

1. https://doi.org/10.2307/3350753

[2] Abdullah, T. (2007). Modernization in the Minangkabau World: West Sumatra in the Early Decades of the Twentieth Century. In C. Holt (Ed.), Culture and Politics in Indonesia. Jakarta - Kuala Lumpur: Equinox Publishing.

[3] Adorno, T. W. (1997). Aesthetic Theory (G. Adorno \& R. Tiedemann (eds.)). London New York: Continuum.

[4] Adorno, T. W., \& Horkheimer, M. (1993). The Culture Industry : Enlightenment as Mass Deception. In Dialectic of Enlightment (pp. 1-24). New York: Continuum.

[5] Anggraini, S. N. (2016). "Aku Yang Galau": Refleksi Film Masa Kolonial Hingga Awal Kemerdekaan. REKAM: Jurnal Fotografi, Televisi, Dan Animasi, 11(2), 79. 
https://doi.org/10.24821/rekam.v11i2.1295

[6] Anwar, Y. W., Zusmelia, \& Nurhuda, A. (2013). Tradisi Pacu Kuda di Minangkabau: Potret yang Berubah 1950-1990 [Tesis]. STKIP PGRI Padang.

[7] Arief, M. (2018). Film Surau dan Silek (Ketika Anak-Anak Menemukan Sebuah Makna) [Laporan Penelitian]. Surakarta.

[8] Arifin, Z. (2012). Buru Babi: Politik Identitas Laki-laki Minangkabau. Humaniora, 24(1), 29-36.

[9] Ashforth, B. E., \& Mael, F. (1989). Social Identity Theory and the Organization. Academic of Management Review, 14(1), 2039.

https://doi.org/10.5465/AMR.1989.4278999

[10] Asmaniar, A. (2018). Perkawinan Adat Minangkabau. Binamulia Hukum, 7(2), 131140.

http://fhunkris.com/journal/index.php/binamulia/artic le/view/23

[11] Azra, A. (2003). Surau: Pendidikan Islam Tradisional dalam Transisi dan Modernisasi (I. Rasyidin (ed.)). Ciputat: Logos.

[12] Bahauddin, A., Hardono, S., Abdullah, A., \& Maliki, N. Z. (2012). The Minangkabau house: Architectural and cultural elements. WIT Transactions on Ecology and the Environment, 165, 15-25. https://doi.org/10.2495/ARC120021

[13] Benda-Beckmann, K. von. (2000). Goyahnya Tangga Menuju Mufakat: Peradilan Nagari dan Pengadilan Negeri di Minangkabau (I. Simbolon (ed.)). Jakarta: PT Gramedia Widiasarana Indonesia bekerja sarna dengan Perwakilan Koninklijk Instituut voor Taal-, Land- en Volkenkunde.

[14] Boggs, J. M., \& Petrie, D. W. (2008). The Art of Watching Film. New York: McGraw-Hill.

[15] Buckland, W. (2000). The Cognitive Semiotics of Film. Cambridge: Cambridge University Press.

[16] Couto, N. (2008). Budaya Visual Seni Tradisi Minangkabau. Padang: Universitas Negeri Padang Press.
[17] Dobbin, C. (2008). Gejolak Ekonomi, Kebangkitan Islam, dan Gerakan Padri (L. D. Tedjasudhana \& F. Nurdiasih (eds.)). Depok: Komunitas Bambu.

[18] Efrida. (2016). Estetika Minangkabau dalam Gerak Tari bujang Sambilan. Jurnal Ekspresi Seni, 18(1), 62-77.

[19] Efrizal. (2010). Estetika dalam Seni Ukir Minangkabau. Ranah Seni, 03(02), 519-530.

[20] Ehrat, J. (2005). Cinema and Semiotic: Peirce and Film Aesthetics, Narration, and Representation. Toronto Buffalo London: University of Toronto Press.

[21] Fadhil, A. (2008). Benarkah Surau Sudah Roboh ? Jurnal Sejarah Lontar, 5(2).

[22] Farid, S., \& Fatimah, S. (2019). Pacu Kudo Attraction in Tanah Datar District and Social Economic Impacts of the Community. International Journal of Progressive Sciences and Technologies, 16(2), 175-182.

[23] Franzia, E. (2017). Cultural Wisdom of Minangkabau Ethnic Community for Local Global Virtual Identity. Mediterranean Journal of Social Sciences, 8(1), 325-329. https://doi.org/10.5901/mjss.2017.v8n1p325

[24] Franzia, E., Piliang, Y. A., \& Saidi, A. I. (2015). Rumah Gadang as a Symbolic Representation of Minangkabau Ethnic Identity. International Journal of Social Science and Humanity, 5(1), 44-49. https://doi.org/10.7763/IJSSH.2015.V5.419

[25] Fulzi, N. (2011). Estetika Musik Talempong Lagu Dendang di Nagari Limbanang. Ekspresi Seni: Jurnal Ilmu Pengetahuan Dan Karya Seni, 13(2), 184-190. https://doi.org/10.1017/CBO9781107415324. 004

[26] Graves, E. E. (2007). Asal-Usul Elite Minangkabau Modern: Respons Terhadap Kolonial Belanda Abad XIX/XX (N. Andri, L. Marlina, \& Nurasni (eds.)). Jakarta: Yayasan Obor Indonesia.

[27] Hadler, J. (2008a). A historiography of violence and the secular state in Indonesia: Tuanku Imam Bondjol and the uses of 
history. Journal of Asian Studies, 67(3), 9711010.

https://doi.org/10.1017/S0021911808001228

[28] Hadler, J. (2008b). Sengketa Tiada Putus: Matriarkat, Reformisme Agama, dan Kolonialisme di Minangkabau. Jakarta: Freedom Institute.

[29] Hamka. (1984). Islam dan Adat Minangkabau. Jakarta: PT Pustaka Panjimas.

[30] Hanan, D. (2017). Cultural Specificity in Indonesian Film: Diversity in Unity. In Cultural Specificity in Indonesian Film: Diversity in Unity. Switzerland: Palgrave Macmillan. https://doi.org/10.1007/978-3319-40874-3

[31] Heider, K. G. (1991). Indonesian Cinema: National Culture on Screen. Honolulu: University of Hawaii Press.

[32] Hole, Y., \& Snehal, P. \& Bhaskar, M. (2018). Service marketing and quality strategies. Periodicals of engineering and natural sciences, 6 (1), 182-196.

[33] Hole, Y., \& Snehal, P. \& Bhaskar, M. (2019). Porter's five forces model: gives you a competitive advantage. Journal of Advanced Research in Dynamical and Control System, 11 (4), 1436-1448.

[34] Ica. (2009). Angkat Pencak Silat Lewat Film "Merantau." Entertainment JPNN.Com. https://www.jpnn.com/news/angkat-pencaksilat-lewat-film-merantau

[35] Indah, N. (2009). "MERANTAU” Kurang Filosofi Silat. KapanLagi.Com. https://www.kapanlagi.com/showbiz/film/ind onesia/merantau-kurang-filosofi-silat.html

[36] Jong, P. D. J. De. (1980). Minangkabau and Negri Sembilan: Socio-pulitical structure in Indonesia. Den Haag: Martinus Nijhoff Uitgeverij.

[37] Kahn, J. S. (1976). “Tradition”, Matriliny and Change among The Minangkabau of Indonesia. Journal of the Humanities and Social Sciences of Southeast Asia, 132(1), 64-95. https://doi.org/10.1163/2213437990002655
[38] Kartika, D. S. (2010). Estetika Nusantara: Orientasi terhadap Filsafat, Kebudayaan, Pandangan Masyarakat, dan Paradigma Seni. In Estetika Nusantara. Surakarta: ISI Press Surakarta.

[39] Kartika, D. S., \& Perwira, N. G. (2004). Pengantar Estetika. Bandung: Rekayasa Sains.

[40] Kato, T. (1978). Change and Continuity in the Minangkabau Matrilineal System. Indonesia, $\quad 25(25), \quad 1-16$. https://doi.org/10.2307/3350964

[41] Kato, T. (1989). Nasab Ibu dan Merantau. Kuala Lumpur: Dewan Bahasa dan Pustaka Kementrian Pendidikan.

[42] Khandizaji, A. (2017). Baudrillard and the Culture Industry: Returning to the First Generation of the Frankfurt School. In Baudrillard and the Culture Industry. Switzerland: Springer. https://doi.org/10.1007/978-3-319-69874-8

[43] Koentjaraningrat. (1980). Sejarah Teori Antropologi I. Jakarta: UI Press.

[44] Kurniasih, N., Rizal, E., Winoto, Y., Kurniawati, N., Sudirman, A., Hasibuan, A., ... \& Saddhono, K. (2018, November). Online Media as a Movie Reference. In Journal of Physics: Conference Series (Vol. 1114, No. 1, p. 012087). IOP Publishing.

[45] Lefebvre, M. (2006). Between Setting and Landscape in the Cinema. In M. Lefebvre (Ed.), Landscape and Film. New York London: Routledge.

[46] Lukinbeal, C. (2005). Cinematic Landscapes. Journal of Cultural Geography, 23(1), 3-22.

[47] Mansoer, M. D., Imran, A., Sarwan, M., Idris, A. Z., \& Buchari, S. I. (1970). Sedjarah Minangkabau. Jakarta: Bhratara Djakarta.

[48] Maresa, A. (2009). Estetika Simbolis Dalam Busana Pengantin Adat Minangkabau Di Padang. Jurnal Filsafat, 19(3), 255-272.

[49] Maude, A. (1979). How circular is Minangkabau migration ? The Indonesian Journal of Geography, 9(37), 1-12.

[50] Metz, C. (1991). Film Language: A Semiotic 
of the Cinema (M. Taylor (ed.)). Chicago: The University of Chicago Press.

[51] Naim, M. (2013). Merantau Pola Migrasi Suku Minangkabau. Yogyakarta: Gadjah Mada University Press.

[52] Nain, S. A., Rosnida, \& Thaher, I. (1988). Kedudukan dan Peranan Wanita dalam Kebudayaan Suku Bangsa Minangkabau. Jakarta: Departemen Pendidikan dan Kebudayaan.

[53] Navis, A. A. (1984). Alam Terkembang Jadi Guru: Adat Dan Kebudayaan Minangkabau. Jakarta: Grafiti Press.

[54] Noviandi, F. (2013). Hanung Bramantyo: Stop Pemutaran Film Cinta Tapi Beda. Liputan6.Com.

https://www.liputan6.com/showbiz/read/4810 65/hanung-bramantyo-stop-pemutaran-filmcinta-tapi-beda

[55] Nur, M. (1991). Gerakan Kaum Sufi di Minangkabau Awal Abad Ke-20 [Tesis Magister]. Yogyakarta: Universitas Gadjah Mada.

[56] Power, D., \& Scott, A. J. (2004). A prelude to cultural industries and the production of culture. In D. Power \& A. J. Scott (Eds.), Cultural Industries and the Production of Culture. London - New York: Routledge.

[57] Prasetya, L. E., \& Adi, S. M. (2011). Makna dan Filosofi Ragam Hias Pada Rumah Tradisional Minangkabau di Nagari Pariangan Tanah Datar. Seminar Nasional "Kearifan Lokal Dalam Keberagaman Untuk Pembangunan Indonesia “, 59-70. Medan.

[58] Priyambodo, A. (2018, November 13). Film Cinta Tapi Beda Diseret ke Jalur Hukum, Ada Apa? Okecelebrity. https://celebrity.okezone.com/read/2018/11/1 7/206/1979281/film-cinta-tapi-beda-diseretke-jalur-hukum-ada-apa

[59] Pugsley, P. C. (2013). Tradition, culture and aesthetics in contemporary Asian cinema. Surrey - Burlington: Ashgate. https://doi.org/10.4324/9781315550381

[60] Rustiyanti, S., Djajasudarma, F., Caturwati,
E., \& Meilinawati, L. (2013). Estetika Tari Minang dalam Kesenian Randai Analisis Tekstual-Kontekstual. Jurnal Seni \& Budaya Panggung, 23(1), 42-56. https://doi.org/10.26742/panggung.v23i1.86

[61] Soenarto, \& Sudyarto, S. (1983). Arsitektur Tradisional Minangkabau Selayang Pandang. Jakarta: Proyek Media Kebudayaan Direktorat Jenderal Kebudayaan Departemen Pendidikan dan Kebudayaan.

[62] Sumardjo, J. (2010). Menemukan Kembali Estetika Nusantara. In Estetika Nusantara. Surakarta: ISI Press Surakarta.

[63] Thalib, A. A. (2017). Isu-Isu Identitas Budaya Nasional dalam Film " Tenggelamnya Kapal Van der Wijck ." Satwika, 1(2). http://ejournal.umm.ac.id/index.php/JICC

[64] Thomson-Jones, K. (2008). Aesthetics and Film. London - New York: Continuum.

[65] Trisnawati, T., \& Yesicha, C. (2018). Representasi Budaya Matrilineal Minangkabau dalam Film Tenggelamnya Kapal van der Wijck. Jurnal Riset Komunikasi, 1(2), 276-284. https://doi.org/10.24329/jurkom.v1i2.40

[66] Turner, G. (2003). Film as social practice (8th ed.). London - New York: Routledge.

[67] Warokka, A., Sjahruddin, H., Sriyanto, S., Noerhartati, E., \& Saddhono, K. (2020). Digital marketing support and business development using online marketing tools: An experimental analysis. International Journal of Psychosocial Rehabilitation, 24(1), 1181-1188. 